\title{
Purification of a Zinc Binding Protein from Xylem of Citrus jambhiri
}

\author{
Kathryn C. Taylor, ${ }^{1}$ Danielle R. Ellis, ${ }^{2}$ and Luciano V. Paiva ${ }^{3}$ \\ Department of Plant Sciences, 303 Forbes Building, University of Arizona, Tucson, AZ 85721
}

\begin{abstract}
ADDITIONAL INDEX WORDS. kunitz soybean proteinase inhibitors, metal-binding proteins, papaya latex trypsin inhibitor, sporamin

ABstract. Zinc in xylem and phloem of the citrus rootstock, rough lemon [Citrus jambhiri $(\mathrm{L})$.$] was associated with a Zn-$ binding protein, designated citrus vascular Zn-binding protein (CVZBP). The apparent molecular mass of the CVZBP was $19.5 \mathrm{kDa}$ after nondenaturing size exclusion chromatography and $21.8 \mathrm{kDa}$ after sodium dodecyl sulfate-polyacrylamide gel electrophoresis. Ion exchange chromatography demonstrated that CVZBP was anionic, requiring $0.43 \mathrm{~N} \mathrm{NaCl}$ for elution from quaternary aminoethyl Sepharose. Antiserum to the protein cross-reacted more with total protein extracts from leaf midveins than with total protein from the rest of the leaf lamina, further suggesting a vascular location of the Zn-binding protein. Quantitative analysis indicated that $\approx 2$ to $3 \mathrm{~mol}$ of $\mathrm{Zn}$ were associated with 1 mol of native protein. Binding studies with the partially purified CVZBP demonstrated a capacity to bind several divalent cations: $\mathrm{Cd}, \mathrm{Ni}, \mathrm{Pb}$, and Zn. Reaction with Ellman's reagent suggested that the protein has significant sulfhydryl group content that may be involved in metal binding. $\mathrm{N}$-terminal sequencing demonstrates identity with papaya latex trypsin inhibitor, sporamin, or other Kunitz soybean proteinase inhibitors.
\end{abstract}

Tree health and longevity appear to be affected by tree $\mathrm{Zn}$ status (Marshner, 1995). In addition, Zn status has been associated with citrus blight, a citrus (Citrus L. sp.) disorder of unknown cause. This decline disorder is characterized by $\mathrm{Zn}$ accumulation in trunk vascular tissues above the bud union (Taylor and Geitzenauer, 1998; Taylor et al., 1988, 1989, 1996; Williams and Albrigo, 1984) and Zn deficiency in the leaves of affected trees. Zinc redistribution is followed by physiological changes that result in decreased water conductivity and tree decline (Albrigo et al., 1986; Brlansky et al., 1984; Vasconcellos and Castle, 1994; Williams and Albrigo, 1984). An abundance of $\mathrm{Zn}$ in trunk phloem of decline-affected citrus (Albrigo et al., 1986) is accompanied by accumulation of Zn-binding factors that appear responsible for trunk phloem Zn sequestration (Taylor et al., 1988). One of these $\mathrm{Zn}$-binding factors, the $5 \mathrm{kDa} \mathrm{Zn}$-binding protein (ZBP), was purified and characterized previously (Taylor and Geitzenauer, 1998; Taylor et al., 1996).

While these previous studies were focused on the site of earliest $\mathrm{Zn}$ accumulation, the phloem, the greatest $\mathrm{Zn}$ accumulation occurs in the xylem of blight affected trees. A Zn-binding factor associated similarly with $Z n$ accumulation in xylem has not been identified previously. Another Zn-binding protein was isolated from citrus vascular tissue (Taylor et al., 1989). The following report is a further characterization of that protein. This novel Zn-binding protein is abundant in xylem and has identity to some members of the Kunitz soybean proteinase inhibitor (KSPI) family.

\section{Materials and Methods}

Plant material. As source material for purification of the citrus vascular Zn-binding protein (CVZBP), xylem evacuate

Received for publication 17 Sept. 2001. Accepted for publication 18 Apr. 2002. This research was supported by the Arizona Citrus Research Council.

${ }^{1}$ Current address: Department of Horticulture, University of Georgia, Southeastern Fruit and Tree Nut Laboratory, 21 Dunbar Rd., Byron, GA 31008; e-mail kctaylor@uga.edu; fax: 478-956-2929.

${ }^{2}$ Current address: Children's Nutrition Research Center, 1100 Bates St., Houston TX 77077.

${ }^{3}$ Current address: Department de Quimica, Universidade Federal de Lavras, UFLA 37200-000, Lavras, MG Brazil. samples were collected from healthy or blight affected trees of Citrus jambhiri grown in a quarantine greenhouse facility on the campus of University of Arizona, Tucson, during 1996. Xylem evacuate was collected by applying $4 \mathrm{~mL}$ of $10 \mathrm{~mm}$ Tris- $\mathrm{Cl}, \mathrm{pH}$ 7.4 to one end of a $10 \mathrm{~cm}$ root piece $>1 \mathrm{~cm}$ diameter while a vacuum was pulled at the other end. Bark was removed from the root piece down to the cambium before evacuation. Before purification, xylem evacuate was stored at $-80^{\circ} \mathrm{C}$. Phloem tissue was sampled as a bark patch taken 15 to $30 \mathrm{~cm}$ above the soil line. Contaminants on the bark surface were removed by scraping away the brown-green outer layer to a $5 \times 10 \mathrm{~cm}$ rectangle of clean whitish phloem tissue. The patch was scored through the scraped bark to the wood and separated from the tree at the cambial layer. The samples were taken from convex surfaces of healthy and blight-affected trees in active growth.

ISOLATION AND PURIFICATION OF CVZBP. To quantitate recovery of CVZBP, three independent purifications were performed. Three separate xylem evacuates (Derrick et al., 1990) were lyophilized and adjusted to $1 \mathrm{~mL}$ each with deionized water. Xylem evacuate was fractionated by ion exchange chromatography (IEC) (Taylor et al., 1996) over quaternary aminoethyl Sepharose (QAE) (Pharmacia, Piscataway, N.J.). Total Zn was determined for aliquots of each fraction by determination of $\mathrm{A}_{213.9}$ by atomic absorption spectrometry (model 3100 , Perkin-Elmer, Shelton, Conn.) and for $254 \mathrm{~nm}$ absorbance $\left(\mathrm{A}_{254}\right)$ by ultraviolet (UV)- spectrophotometry. Fractions with elevations of $\mathrm{A}_{254}$ and coincident elevated $\mathrm{Zn}$ were pooled and the volume reduced in a centrifugal vacuum concentrator (model RC 10. 10; Jouan, Winchester, Va.). Concentrated Zn-containing eluant from QAE chromatography was separated using a $2.5 \times 14 \mathrm{~cm}$ gel filtration (GF) column of Bio-Gel P-30 (Bio-Rad, Hercules, Calif.) in 10 mm Tris-Cl buffer, $\mathrm{pH} 8.0\left(4{ }^{\circ} \mathrm{C}\right)$ in $3 \mathrm{~mL}$ fractions. Fractions within the peaks of $\mathrm{A}_{254}$ and elevated $\mathrm{Zn}$ content were pooled, trichloroacetic acid precipitated (Deutscher, 1990), and further purified by sodium dodecyl sulfate-polyacrylamide gel electrophoresis (SDS-PAGE) (Laemmli, 1970). For all isolation steps, total protein was determined at $\mathrm{A}_{595}$ with Quantigold (Diversified Biotech, Newton Centre, Mass.) or with the Bradford assay (Bio$\mathrm{Rad})$, depending upon protein concentration with each stage of purification. 
Table 1. Total protein and $\mathrm{Zn}$, specific $\mathrm{Zn}$ content ( $\mu \mathrm{g} \mathrm{Zn} / \mathrm{mg}$ protein), and protein concentration during purification of CVZBP from healthy and blight affected tissues of Citrus jambhiri. ${ }^{\mathrm{z}}$

\begin{tabular}{|c|c|c|c|c|c|c|c|c|}
\hline Sample $^{y}$ & \multicolumn{4}{|c|}{ Healthy tissue } & \multicolumn{4}{|c|}{ Blight-affected tissue } \\
\hline \multicolumn{9}{|c|}{ Crude extract } \\
\hline Phloem & 30 & 72.8 & 0.0024 & 3.02 & 30 & 274.4 & 0.0091 & 5.87 \\
\hline Phloem & 6.0 & 12.3 & 2.1 & 0.60 & 4.3 & 16.4 & 3.8 & 0.84 \\
\hline Xylem & 8.5 & 38.8 & 4.6 & 1.85 & 7.9 & 34.7 & 4.4 & 2.69 \\
\hline \multicolumn{9}{|l|}{ GF } \\
\hline Phloem & 0.292 & 1.5 & 5.1 & 0.03 & 0.271 & 1.7 & 6.3 & 0.05 \\
\hline Xylem & 0.425 & 4.1 & 9.7 & 0.13 & 0.639 & 6.2 & 9.6 & 0.29 \\
\hline
\end{tabular}

${ }^{\mathrm{Z}}$ Each value is based on three column purifications.

yIEC $=$ ion exchange chromatography and GF = gel filtration chromatography.

GF purified CVZBP $(50 \mathrm{mg})$ was electrophoresed for $1.5 \mathrm{~h}$ at $150 \mathrm{~V}$, constant voltage, in a $\mathrm{pH} 8.3$ Laemmli buffer system (Laemmli, 1970). Gels were silver stained (Morrisey, 1981). Following SDS-PAGE of samples containing $200 \mathrm{mg}$ protein, two nonstained lanes were sliced across their width into $0.5 \mathrm{~cm}$ fractions down the length of the gel. Each gel fraction was eluted in $1.0 \mathrm{~mL}$ of $0.5 \% \mathrm{HCl}$ (Trace metal grade) in high-performance liquid chromatography (HPLC) grade water. Total $\mathrm{Zn}$ content eluted from each gel slice was determined by atomic absorption spectrometry. The isoelectric point (pI) for the GF purified CVZBP was determined as described previously (Taylor et al., 1996).

ELLMAN'S DETERMINATION OF SULFHYDRYL GROUPS IN CVZBP. Ellman's reactions (Ellman, 1959) were performed to assess the sulfhydryl content associated with the GF-purified fractions, since they are often involved in protein associations with transition metals (Vallee and Auld, 1990). Fractions eluted from GF columns were assessed for the presence of sulfhydryl containing residues in the CVZBP. This was accomplished by additional postcolumn sulfhydryl group derivatization with $75 \mu \mathrm{M}$ Ellman's reagent, 5,5' dithobis (2-nitrobenzoic acid in $50 \mathrm{~mm}$ potassium phosphate buffer ( $\mathrm{pH}$ 7.6). Sulfhydryl determinations were made at $410 \mathrm{~nm}$.

IMMUNOCHEMISTRY. IEC and GF purified CVZBP were separated by preparative SDS-PAGE. Gels were stained in Coomassie Brillant Blue R in 5 distilled water : 1 acetic acid : 5 methanol (by volume) for 5 min to identify the band of interest. After a 30 to 45 min destain, CVZBP bands were cut out of the gels. The gel pieces were used for anti-serum preparation as described previously (Taylor et al., 1996). Crude phloem extract was used in immunoblot analyses to assess purity of the serum. In addition, leaves were dissected to assess location of the CVZBP with relation to vascular tissue. For all immunoblot analyses, $10 \mathrm{mg}$ of crude protein extract was loaded onto $20 \%$ SDS-PAGE gels. Following SDS-PAGE, proteins were transferred to $0.45 \mu \mathrm{m}$ poly (vinylidene diflouride) membrane in the buffer of Towbin et al. (1979). Electrotransfer was accomplished with the Bio-Rad Mini TransBlot apparatus in $45 \mathrm{~min}$. Blots were blocked overnight in $1 \%$ bovine serum albumin in buffer [ $10 \mathrm{~mm}$ Tris-Cl, $\mathrm{pH} 8.0,150 \mathrm{~mm}$ $\mathrm{NaCl}, 0.05 \%$ Tween-20 (TBST)]. Detection was performed by incubating blots in a 1:1000 dilution of anti-CVZBP rabbit serum in TBST followed by incubation in a 1:200 dilution of alkaline phosphatase labeled goat antirabbit serum (Sigma, St. Louis) in TBST. The immunoblot was developed as in King et al. (1985).

DETERMINATION OF AMINO ACID COMPOSITION AND N-TERMINAL SEQUENCE. For amino acid composition and N-terminal sequencing, a denaturing gel was electroblotted in CAPS buffer (Matsudaira, 1987), lightly stained with Coomassie Brillant Blue $\mathrm{R}$, and the major band was cut out of the membrane. Amino acid analysis of the CVZBP was completed at the University of Arizona, Laboratory for Protein Sequencing and Analyses, Tucson, using an amino acid analyzer (ABI $420 \mathrm{~A} / \mathrm{H}$; Applied Biosystems, Foster City, Calif.). The protein was hydrolyzed in vapor phase using $6 \mathrm{~N} \mathrm{HCl}$ at $155^{\circ} \mathrm{C}$ for $75 \mathrm{~min}$, then derivitized with phenylisothiocyanate to form phenylthiocarbamyl amino acid derivatives which were extracted and transferred to on-line HPLC for analysis of $\mathrm{A}_{254}$. Dimethyl sulfoxide (DMSO) hydrolysis was required before amino acid analysis to determine cysteine as cysteic acid (Spencer and Wold, 1969). Results of the $6 \mathrm{~N} \mathrm{HCl}$ and DMSO hydrolyses were combined for reporting purposes.

Using Edman chemistry, the $\mathrm{N}$-terminal amino acid sequence of the purified CVZBP was determined at the University of Arizona Laboratory for Protein Sequencing and Analysis using a 477A Protein/Peptide sequencer (Applied Biosystems) interfaced with a 120A HPLC (C-18 PTH column, reverse phase chromatography) analyzer to determine PTH amino acids. The $\mathrm{N}$-terminal sequence was analyzed by BLAST searches for identity and similarity with other reported sequences in National Center for Biotechnology Information Genebank.

VOLTAMETRIC DETERMINATION OF RESIDUAL METAL-BINDING CAPACITY OF CVZBP. The voltametric method, differential pulse polarography, was used as a measure of the residual complexation capacity for the divalent cations, $\mathrm{Zn}, \mathrm{Cd}, \mathrm{Ni}$, and $\mathrm{Pb}$ (Street and Petersen, 1982; Taylor et al., 1988). Differential pulse polarography was used to determine the capacity of IEC/ GF-purified CVZBP to reduce the level of free metal ion in a 5 $\mathrm{mM}$ metal ion solution in $0.1 \mathrm{M} \mathrm{KNO}_{3}$. To the metal ion solution, $10 \mathrm{mg}$ total protein was added. A polarographic analyzer with a static mercury electrode (model 384B and model 303A, respectively; EG and G Princeton Applied Research, Princeton, N.J.) were used for the assays. Differential pulse polarography was performed over the range of -0.800 to $-1.200 \mathrm{~V}$ with a drop/step time of $0.6 \mathrm{mV} \cdot \mathrm{s}^{-1}$. Calculations of free metal ion concentration were made on the basis of the total $10 \mathrm{~mL}$ assay mixture. A 


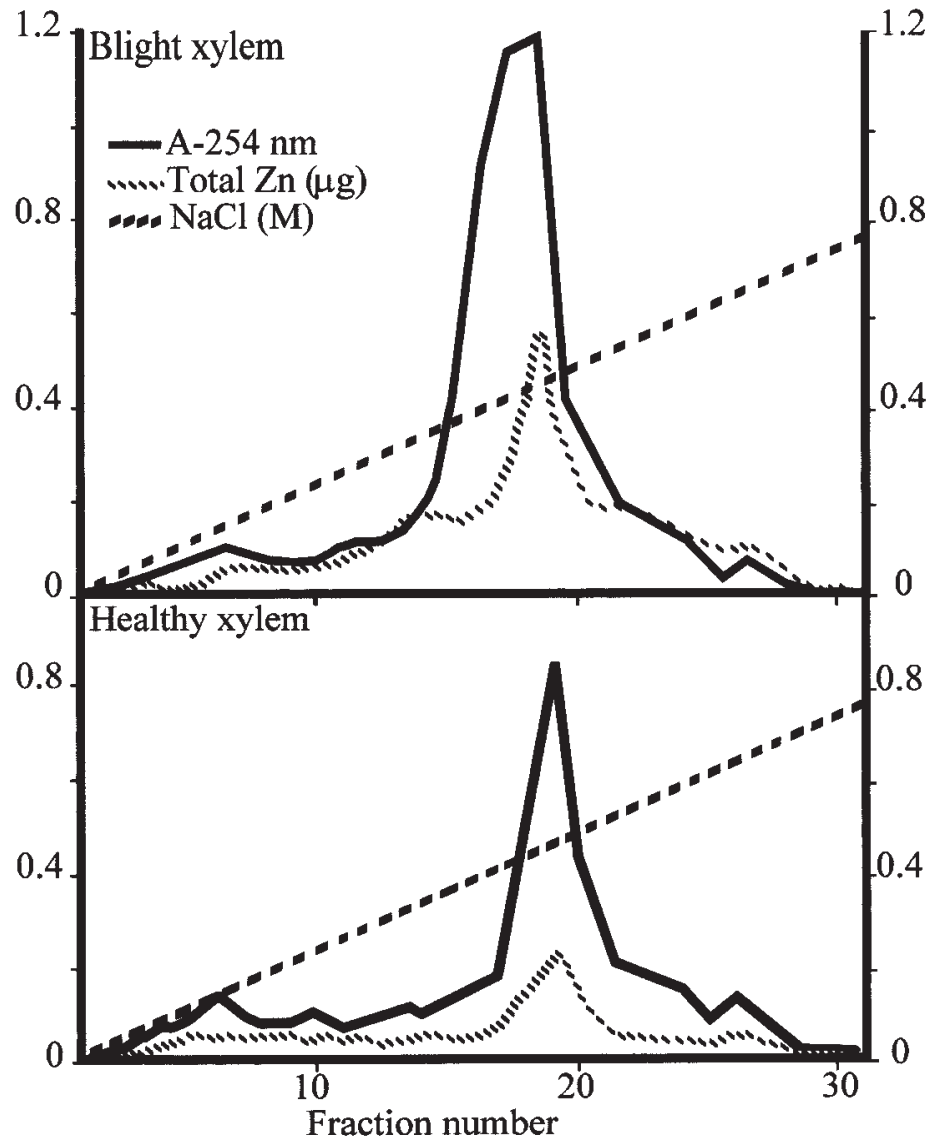

Fig. 1. Elution profile of protein extracts from QAE-sepharose ion exchange column. Zinc content was coincident with elevated $\mathrm{UV}_{254 \mathrm{~nm}}$ of metal-ion chromophores.

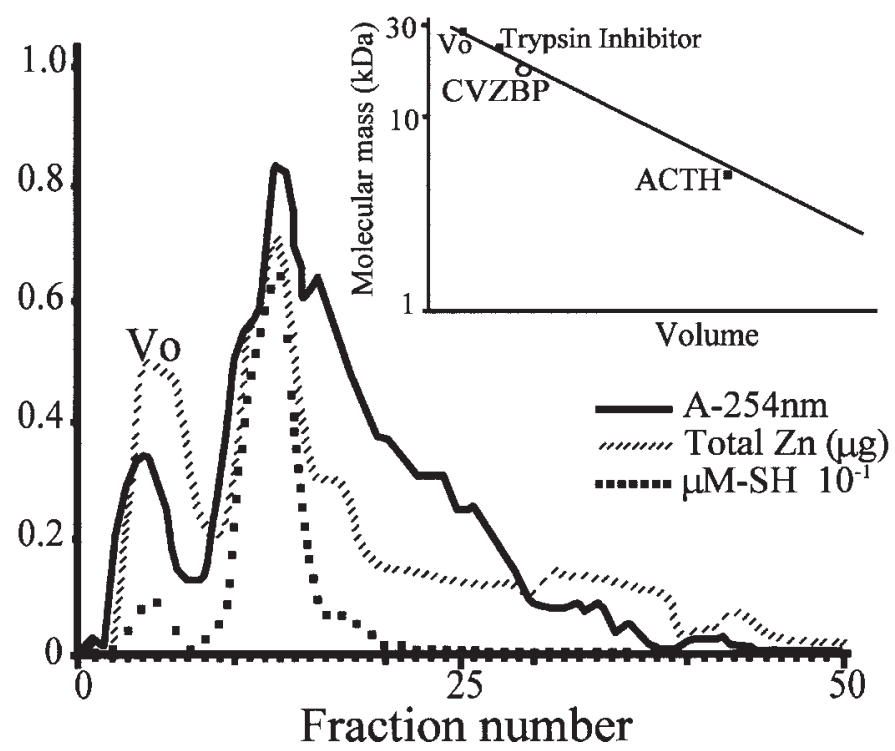

Fig. 2. Elution profile of pooled QAE fractions from Bio-Gel P30 column. Zinc containing peaks also absorbed UV at $254 \mathrm{~nm}$. Insert: Calibration curves for the elution of the CVZBP from the Biio-Gel P30 Column. The size exclusion elution profile was calibrated for molecular masses with $3 \mathrm{mg}$ each of soybean trypsin inhibitor $\left(20,100 \mathrm{M}_{\mathrm{r}}\right)$ and adrenocorticotropic hormone (ACTH, 4,500 $\mathrm{M}_{\mathrm{r}}$ ). The void volume was determined by blue dextran (Vo, 2,000,000 $\mathrm{M}_{\mathrm{r}}$ ) elution. reduction of the concentration of free metal ion was assumed to be an indication of the level of metal ion complexed by the CVZBP.

\section{Results}

ACCOUnT OF ZINC AND PRoteIn THROUGH THE PURIFICATION OF CVZBP. The CVZBP was most abundant in xylem tissue of blight affected citrus. After IEC and GF purification, the CVZBP was present in higher amounts in xylem evacuate than phloem tissue on a total protein basis (1.4- to 2.4-fold more in xylem than phloem) (Table 1). Four to seven times more of the total protein from the xylem evacuate was accounted for by the CVZBP than total protein from phloem ( $4.3 \%$ to $6.4 \%$, xylem; $0.9 \%$ to $1.0 \%$, phloem). The ratio of $\mathrm{Zn}$ to purified protein indicated that purification of the CVZBP from phloem and xylem was as much as 2125- and 1560-fold, respectively (Table 1). CVZBP was eluted from xylem evacuate of blight affected citrus at 2.2-fold greater level than from xylem evacuate of healthy citrus, while CVZBP elution was similar from phloem tissue extracts of blight and healthy citrus (Table 1). Quantitative analysis of $\mathrm{Zn}$ and protein from the three separate purifications of CVZBP from xylem and phloem agreed.

The anionic CVZBP was eluted from QAE Sepharose by 0.43 $\mathrm{M} \mathrm{NaCl}$ (Fig. 1). Based upon two methods to estimate molecular mass, chromatography and electrophoresis, we placed the apparent molecular mass of this $\mathrm{Zn}$-binding protein at $22 \mathrm{kDa}$. The $\mathrm{Zn}$ peak contained a protein of $\approx 19.5 \mathrm{kDa}$ (Fig. 2), as determined by nondenaturing GF chromatography. This relative mobility was less than the apparent molecular mass of $21.8 \mathrm{kDa}$ determined by the denaturing conditions of SDS-PAGE (Fig. 3). Direct preparative isoelectric focusing data indicated that the protein had a $\mathrm{pI}$ of 5.5 (data not presented).

DiRECT CORRELATION OF PUTATIVE CVZBP WITH PRESENCE OF ZINC. We were able to directly assess the concentration of $\mathrm{Zn}$ in SDS-PAGE gels, after elution from the sequentially dissected gel pieces. Zn was correlated with a $21.8 \mathrm{kDa}$ protein band (Fig. 3), which was the band that cross-reacted with the anti-CVZBP serum. In addition, the $\mathrm{Zn}$-containing preparative isoelectric focusing fractions contained protein that had an apparent molecular mass of $22 \mathrm{kDa}$ (gels not shown).

ELLMAN'S DETERMINATION OF SULFHYDRYL GROUPS IN CVZBP. To assess the sulfhydryl group content of the IEC/GF purified CVZBP, Ellman's reactions (Ellman, 1959) were performed. Assessing only the xylem evacuate from blight affected citrus we determined that the peak of partially purified sample contained $\approx$ $6.7 \mu \mathrm{M}$ sulfhydryl groups (Fig. 2). More importantly, the sulfhydryl content was coincident with the $\mathrm{Zn}$ and $\mathrm{A}_{254}$ elution profiles.

RESIDUAL METAL BINDING CAPACITY OF CVZBP. The capacity of CVZBP to continue to bind $\mathrm{Zn}$ under the generally denaturing conditions of SDS-PAGE suggested an extremely stable association of this protein with $\mathrm{Zn}$. Therefore, CVZBP was assessed for its capacity to not only sequester additional levels of $\mathrm{Zn}$, but also $\mathrm{Cd}, \mathrm{Ni}$, and $\mathrm{Pb}$ above the $\mathrm{Zn}$ already bound by the protein, to develop a profile of the capacity of the protein to bind relative quantities of other divalent ions. In this binding study, $1 \mathrm{mg} \cdot \mathrm{mL}^{-1}$ of the IEC/GF purified CVZBP was placed in $5 \mathrm{mM}$ concentrations of each metal individually. The protein bound all metal ions tested at differing molar concentrations (Table 2) in the following sequence $\mathrm{Pb}>\mathrm{Cd} \geq \mathrm{Ni} \geq \mathrm{Zn}$.

IMMUNOCHEMICAL DETERMINATION OF CVZBP ACCUMULATION IN VASCUlar TISSUE. Although CVZBP was extracted from the 


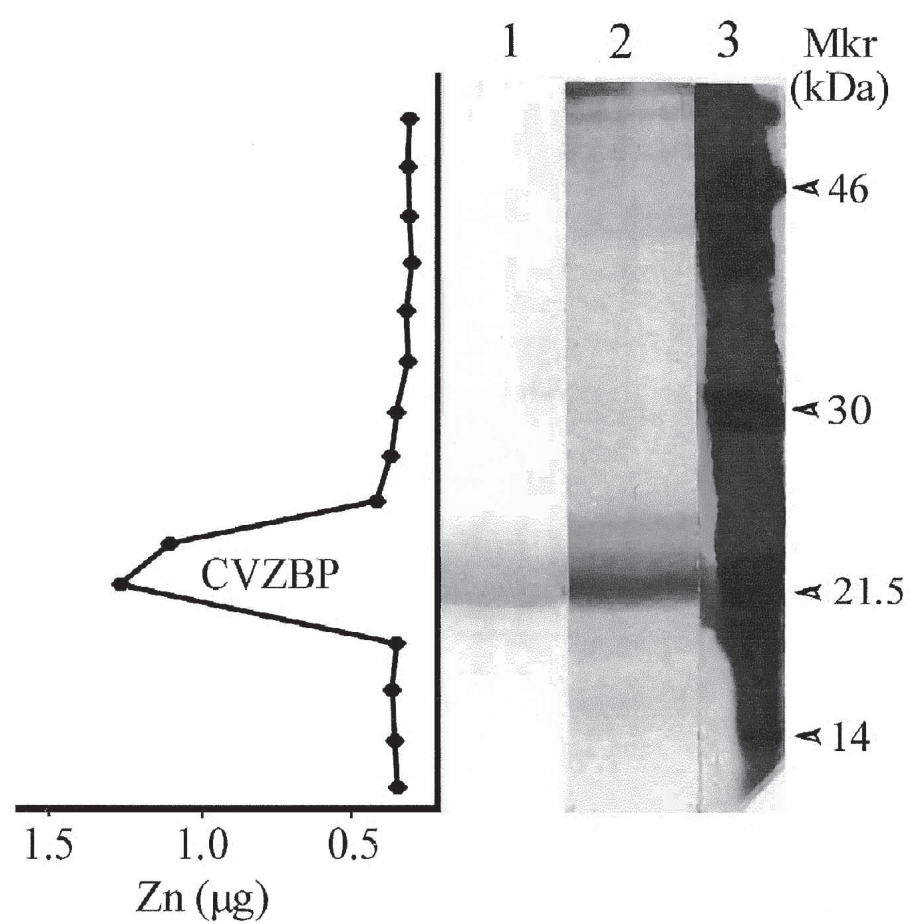

Fig. 3. Direct correlation of CVZBP with presence of Zn. Purified CVZBP separated on SDS-PAGE gel adjacent to graph that indicates the level of $\mathrm{Zn}$ eluted from $0.5-\mathrm{cm}$ gel slices from the $11 \mathrm{~cm}$ gel. Lane $1=$ immunoblot of purified CVZBP; lane 2 = silver stained lane from the same gel; and lane $3=$ molecular mass markers (Mkr). This gel was overloaded and over stained to show apparent purification of CVZBP.

Table 2. Residual metal-binding capacity of $\mathrm{Pb}, \mathrm{Ni}, \mathrm{Cd}$, and $\mathrm{Zn}$ by GFpurified CVZBP above the level of $\mathrm{Zn}$ associated with the protein after its isolation. Five micromolar solutions of each metal was supplied to a $1 \mu \mathrm{g} \cdot \mathrm{mL}^{-1}$ solution of GF-purified CVZBP.

\begin{tabular}{lc}
\hline \hline $\begin{array}{l}\text { Metal } \\
\text { ion }\end{array}$ & $\begin{array}{c}\text { Metal binding } \\
(\text { mean } \pm \mathrm{SD})^{\mathrm{z}}\end{array}$ \\
\hline $\mathrm{Cd}$ & $0.79 \pm 0.15$ \\
$\mathrm{Ni}$ & $0.65 \pm 0.11$ \\
$\mathrm{~Pb}$ & $1.15 \pm 0.32$ \\
$\mathrm{Zn}$ & $0.55 \pm 0.06$ \\
\hline
\end{tabular}

${ }^{\mathrm{z}}$ Each mean is based on 10 observations.

phloem and xylem of $C$. jambhiri, it was necessary to determine its specificity to vascular tissues. In an immunochemical determination of CVZBP accumulation, total protein was extracted from whole leaves of $C$. jambhiri and leaves that had been dissected into midveins and remaining laminae to determine if the proteins might be specific to the vascular tissue in the leaf. The CVZBP was most abundant in the more densely vascular midvein extracts and apparently absent in the whole leaf and laminal extracts (Fig. 4). Along with the xylem and phloem isolations of this protein, the midvein localization further suggested a vascular location for CVZBP. When equivalent amounts $(10 \mu \mathrm{g})$ of IEC/GF purified CVZBP from xylem and phloem were separated by SDS-PAGE followed by immunoblot analysis, they were equally reactive to the anti-CVZBP serum.

Amino ACID composition. Amino acid analysis (Table 3) revealed that $\mathrm{CVZBP}$ contained seven cysteine and four histidine residues. These residues are often involved in metal binding of Zn-finger containing proteins (Berg, 1986; Vallee et al., 1991) such as metallothionein. In addition, the composition was rich in aspartate/asparagine and glutamate/glutamine. The acid forms may participate in metal binding through carboxyl moieties of the R-groups (Vallee and Auld, 1990).

N-TERMinal AMINo ACID SEQUENCE. The first 27 residues of the amino acid sequence contained no cysteine molecules. However, the sequence was indicative of the $\mathrm{N}$-terminal sequence of sporamin (Hattori et al., 1985), papaya latex trypsin inhibitor (Odani et al., 1996), and other Kunitz-type proteinase inhibitors (Fig. 5), members of the KSPI superfamily of genes. The N-terminal sequence had $52 \%$ identity and $67 \%$ similarity with the N-terminal sequence of papaya latex trypsin inhibitor, $48 \%$ identity and $59 \%$ similarity with the N-terminal sequence of sporamin A and B precursors (Hattori et al., 1985, 1989; Koide et al., 1997), and $48 \%$ identity with the N-terminal sequence of chymotrypsin inhibitor WCI-3 (Habu et al., 1997; Sakata et al., 1997). The KSPI family includes serine, aspartic and cysteine proteinase inhibitors from a variety of plant families (Gruden et al., 1997; Jokufu and Goldberg, 1989; Leah and Mundy, 1989; Spencer and Hodge, 1991; Trumper et al., 1994), along with other proteins of similar identity but unknown function (Masuda et al., 1995; Theerasilp et al., 1989) such as miraculin.

\section{Discussion}

We isolated and characterized a novel CVZBP that appears to be localized primarily in the xylem and is 2.2 times more abundant in xylem of blight affected citrus than xylem of healthy citrus. The CVZBP was associated with the xylem $\mathrm{Zn}$ accumulation that characterizes citrus blight. CVZBP has N-terminal identity with papaya latex trypsin inhibitor, sporamin A and B precursors, and chymotrypsin inhibitor, members of the KSPI protein family. The N-terminal amino acid residue of the CVZBP (Fig. 5) was aspartic acid. Lack of an N-terminal methionine residue suggests that $\mathrm{CVZBP}$ has a propeptide that is removed after processing. The presence of propeptides has been demonstrated for several members of the KSPI family (Gruden et al., 1997; Koide et al., 1997; Masuda et al., 1995; Spencer and Hodge, 1991).

We estimated the molecular mass of this protein at $22 \mathrm{kDa}$, despite the molecular mass disparity between nondenaturing and denaturing conditions. This difference with purification conditions is not surprising. Amino acid analysis (Table 3) predicted an intermediate molecular mass of $21.4 \mathrm{kDa}$ for a protein containing 175 amino acid residues. It is likely that the CVZBP was not completely denatured by the typical SDS-PAGE method of Laemmli (1970), since $\mathrm{Zn}$ remained associated with the protein throughout SDS-PAGE (Fig. 3), resulting in a size estimate that was larger than the composition suggested.

A key characteristic of members of the KSPI family is the

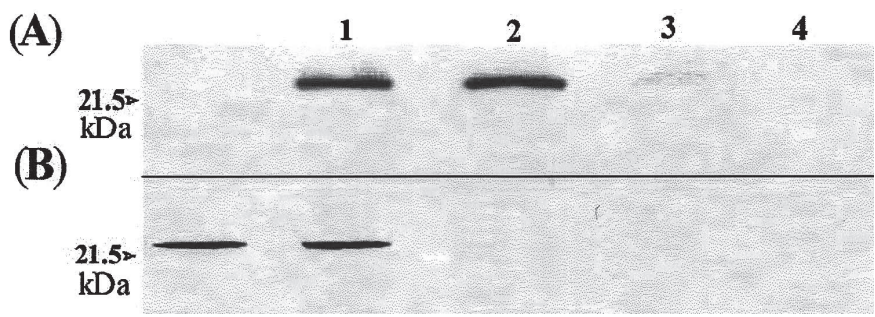

Fig. 4. Western blot analysis for CVZBP in citrus. (A) Lane $1=$ molecular mass marker; lane $2=$ positive control, $5 \mu \mathrm{g}$ of protein extract of trunk phloem tissue; lane 3 to $10 \mu \mathrm{g}$ of protein extract of leaf midvein; lane $4=10 \mu \mathrm{g}$ of protein extract of whole leaves; and lane $5=10 \mu \mathrm{g}$ of protein extract of leaves without midvein. (B) Lane $1=10 \mu \mathrm{g}$ of protein extract of trunk phloem tissue; and lane $2=10 \mu \mathrm{g}$ of protein xylem evacuate $(500 \times$ concentrate). 
Table 3. Amino acid composition of CVZBP.

\begin{tabular}{lcc}
\hline \hline $\begin{array}{l}\text { Amino acid } \\
\text { residues }\end{array}$ & $\begin{array}{c}\mathrm{nM} \\
(\%)\end{array}$ & $\begin{array}{c}\text { Estimated no. } \\
\text { of residues }\end{array}$ \\
\hline Asx ${ }^{z}$ & 12.6 & 22 \\
Valine & 10.8 & 19 \\
Glycine & 9.4 & 16 \\
Arginine & 9.0 & 16 \\
Serine & 8.0 & 14 \\
Threonine & 6.3 & 14 \\
Glx & 6.3 & 11 \\
Leucine & 8.1 & 11 \\
Alanine & 5.1 & 9 \\
Cysteine & 4.1 & 7 \\
Proline & 3.4 & 6 \\
Isoleucine & 3.4 & 6 \\
Phenylalanine & 3.3 & 6 \\
Lysine & 3.3 & 6 \\
Histidine & 2.3 & 4 \\
Tyrosine & 1.7 & 3 \\
Tryptophan & 1.7 & 3 \\
Methionine & 1.2 & 2 \\
Total & 100 & 175 \\
\hline
\end{tabular}

${ }^{\mathrm{z}}$ Asx and Glx $=$ asparagine + aspartate and glutamine + glutamate, respectively.

presence of two disulfide domains, one in the $\mathrm{N}$-terminal region and one at the $\mathrm{C}$-terminus. The CVZBP amino acid composition suggested that the sequence contained seven cysteines and four histidines, which can be involved in metal binding. This result was supported by the Ellman's reaction determination (Fig. 2) that demonstrated the presence of sulhydryl groups consistent with the presence of cysteine residues. Several KSPIs contain a similar number of cysteine residues, with four arranged into a domain near the carboxy end of the molecules. Two of these four residues have been demonstrated to form a disulfide bond in miraculin (Igeta et al., 1991). Although some other KSPI members contain additional cysteines, the presence of an additional disulfide bond is demonstrated only in miraculin, which suggests that in at least one member of this family the additional cysteines are crosslinked and this motif is not available to bind metal. However in the CVZBP, it is not improbable that $\mathrm{Zn}$ could be stably bound by any of these cysteine pairs replacing the disulfide bonds, with a metal ion crosslinked between them as in the Cdbinding domain of metallothionein. Two KSPI members, the 21 $\mathrm{kDa}$ seed protein from Theobroma cacao L. (cacao) (Spencer and Hodge, 1991) and miraculin (Igeta et al., 1991), have amino acid sequence identity with the metal binding domains of metallothionein (deMiranda et al., 1990; Evans et al., 1990) and Ferridoxin II (Berg, 1986) relative to cysteine arrangement in the C-terminal third of the protein. In metallothionein, one domain is correlated with sequestration of three metal ions (Vallee and Auld, 1990), similar to the stochiometry we have noted in CVZBP purification. In fact our Zn/CVZBP quantitation (gel filtration, Table 1) suggests Zn:CVZBP molar ratios in this range (with 1.77 and 3.33 for phloem and xylem purified CVZBP, respectively). Differential pulse polarography data (Table 2) for GF-purified metal binding fractions

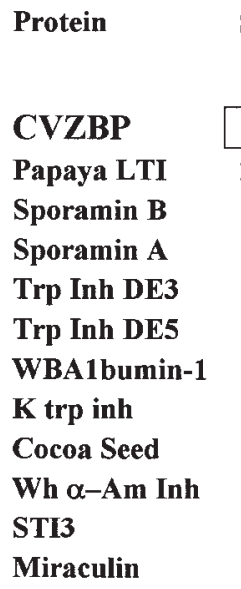

Sequence

$\%$ ID/ \% SIM

Swiss-Prot

database no.

\begin{tabular}{|c|c|c|c|}
\hline -DPLVDVHGN & KVEASRDYYL & VSAIRGAG & 100 \\
\hline $\mathrm{PK} \cdot \mathrm{T} \cdot \mathrm{B} \cdot \mathrm{D}$ & $\mathrm{P} \cdot \mathrm{LYGV} \cdot \mathrm{K}$ KV & $\cdots \mathrm{W}$ & $52 / 67$ \\
\hline$--\cdot V \cdot \cdot 3 \mathrm{~N} \cdot \mathrm{D}$ & ER $\cdot$ GEN $\cdot M-$ & $\cdots \cdot \mathrm{w} \cdot \cdots$ & $48 / 59$ \\
\hline$--\cdot V \% \cdot \mathrm{TN}_{\mathrm{N}} \cdot \mathrm{D}$ & $E R \cdot G G N \cdot \cdot M-$ & $\cdots \cdot \mathrm{W} \cdot \cdots$ & $48 / 59$ \\
\hline$--\cdots \cdots$ & $\mathrm{L} \cdot \mathrm{NGGT} \cdot \cdots$ & WH - WAI. & $48 / 56$ \\
\hline$---\cdot D \cdot D$ & 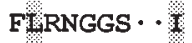 & $\cdot P \cdot F \cdot \cdot K \cdot$ & $44 / 56$ \\
\hline$-\cdots \mathrm{VY} \cdot \mathrm{AE} \cdot \cdot$ & - LVNRGK $\cdot$ TI & $\cdots$ FSD $\cdots$ & $44 / 56$ \\
\hline$-R E \cdot L \cdot D \cdot$ & 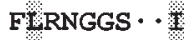 & $\cdot \mathrm{P} \cdot \mathrm{F} \cdot \cdot \mathrm{K} \cdot$ & $44 / 56$ \\
\hline$--\cdot V \cdot T D \cdot D$ & ELOTGNQ $\cdot V$ & W.s.s. & $37 / 56$ \\
\hline$--\cdot \gamma_{H} \cdot T D \cdot \cdot$ & ELR $\cdot D A N \cdot \cdot Y$ & $\mathrm{MP} \cdot \mathrm{N} \cdot \mathrm{AH} \cdot$ & $37 / 52$ \\
\hline$---V Y \cdot N E \cdot$ & $\mathrm{PL} \cdot \mathrm{NGGT} \cdot \mathbf{T}$ & W. D $\cdot$ TAF & $33 / 52$ \\
\hline$-\mathrm{N} \cdot V_{\mathrm{H}} \cdot$ ED $=\mathrm{E}$ & - LRTGTN $\cdot$ II & $\cdot \mathrm{PVL} \cdot \mathrm{DH} \cdot$ & $33 / 48$ \\
\hline
\end{tabular}

P80691

P14716

P14715

P07475

P09941

P15465

P25272

P32765

P16347

P01070

P13087 
inhibitor gene family: Molecular cloning, characterization and immunocytochemical localization studies. Plant Mol. Biol. 34:317-323.

Habu, Y., S. Peyachoknagul, Y. Sakata, F. Fukasawa, and T. Ohno. 1997. Evolution of a multigene family that encodes the Kunitz chromotrypsin inhibitor in winged bean: A possible intermediate in the generation of a new gene with a distinct pattern of expression. Mol. Gen. Genet. 254:73-80.

Hattori, T., T. Nakagawa, M. Maeshima, K. Nakamura, and T. Asahi. 1985. Molecular cloning and nucleotide sequence of cDNA for sporamin, the major soluble protein of sweet potato tuberous roots. Plant Mol. Biol. 5:313-320.

Hattori, T., N. Yoshida, and K. Nakamura. 1989. Structural relationship among the members of a multigene family coding for the sweet potato tuberous root storage protein. Plant Mol. Biol. 13:563-572.

Igeta, H., Y. Tamura, K. Nakaya, Y. Nakamura, and Y. Kurihara. 1991. Determination of disulfide array and subunit structure of taste-modifying protein, miraculin. Biochem. et Biophys. Acta. 1079:303-307.

Jofuku D.K. and R.B. Goldberg. 1989. Kunitz trypsin inhibitor genes are differentially expressed during the soybean life cycle and in transformed tobacco plants. Plant Cell 1:1079-1093.

King, S.M., T. Otter, and G.B. Witman. 1985. Characterization of monoclonal antibodies against Chlamaydomonas flagellar dyneins by high resolution protein blotting. Proc. Natl. Acad. Sci. USA 82:4717.

Koide, Y., H. Hirano, K. Matsuoka, and K. Nakamura. 1997. The Nterminal propeptide of the precursor to sporamin acts as a vacuoletargeting signal even at the $\mathrm{C}$ terminus of the mature part in tobacco cells. Plant Physiol. 114:863-870.

Laemmli, U.K. 1970. Cleavage of structural proteins during the assembly of the head of bacteriophage T4. Nature 227:68-685.

Leah, R. and J. Mundy. 1989. The bifunctional $\alpha$-amylase/subtilisin inhibitor of barley: Nucleotide sequence and patterns of seed-specific expression. Plant Mol. Biol. 12:673-682.

Marschner, H. 1995. Mineral Nutrition of Higher Plants. $2^{\text {nd }}$ ed. Academic Press, Inc., San Diego.

Masuda, Y., S. Nirasawa, K. Nakaya, and Y. Kurihara. 1995. Cloning and sequencing of a cDNA encoding and taste-modifying protein, miraculin. Gene 161:175-177.

Matsudaira, P. 1987. Sequence from picomole quantities of proteins electroblotted onto polyvinylidnene difluoride membranes. J. Biol. Chem. 262:10035-10038.

Morrisey, J.H. 1981. Silver stain for proteins in polyacrylamide gels: A modified procedure with enhanced uniform sensitivity. Anal. Biochem. 117:307-310.

Odani, S., Y. Yokokawa, H. Takeda, S. Abe, and S. Okani. 1996. The primary structure and characterization of carbohydrate chains of the extracellular glycoprotein proteinase inhibitor from latex of Carica papaya. European J. Biochem. 241:77-82.

Sakata, Y., Y. Chiba, H. Fukushima, N. Matsubara, Y. Habu, S. Naito, and T. Ohno. 1997. The RY sequence is necessary but not sufficient for the transcription activation of a winged bean chymotrypsin inhibitor gene in developing seeds. Plant Mol. Biol. 34:191-197.

Spencer, M.E. and R. Hodge. 1991. Cloning and sequencing of the cDNA encoding the major albumin of Theobroma cacao. Planta 183:528-535.

Spencer, R.L. and F. Wold. 1969. A new convenient method for estimation of total cystine-cysteine in proteins. Anal. Biochem. 32:185.

Street, J.J. and W.M. Petersen. 1982. Anodic stripping and differential pulse polarography, p.112-141. In: A.L. Page, R.H. Miller, and D.R. Keeney (eds.). Methods of soil analysis: Part 2. Chemical and microbiological properties. $2^{\text {nd }}$ ed. Amer. Soc. of Agron., Soil Sci. Soc. of Amer., Madison, Wis.

Taylor, K.C., L.G. Albrigo, and C.D. Chase. 1988. Zinc complexation in the phloem of blight-affected citrus. J. Amer. Soc. Hort. Sci. 113:407411.

Taylor, K.C., L.G. Albrigo, and C.D. Chase. 1989. Characterization of a $\mathrm{Zn}$-binding peptide associated with a decline disorder in citrus, $\mathrm{p}$. 385-394. In: D. Winge and D. Hamer (eds.). UCLA symposium on metal ion homeostasis: Molecular biology and chemistry. Alan R. Liss, Inc., New York.

Taylor, K.C., L.G. Albrigo, and C.D. Chase. 1996. Purification of a Znbinding phloem protein with sequence identity to chitin-binding proteins. Plant Physiol. 110:657-664.

Taylor, K.C. and H.L. Geitzenauer. 1998. 5-kD zinc-binding protein accumulation in macrophylla-decline-affected citrus. J. Amer. Soc. Hort. Sci. 123:357-360.

Theerasilp, S., H. Hitotsuya, S. Nakajos, K. Nakayas, Y. Nakamuras, and Y. Kurihara. 1989. Complete amino acid sequence and structure characterization of the taste-modifying protein, miraculin. J. Biol. Chem. 264:6655-6659.

Towbin, H., T. Staehlin, and T. Gordon. 1979. Electrophoretic transfer of proteins from polyacrylamide gels to nitrocellulose sheets. Proc. Natl. Acad. Sci. USA 76:4350-4354.

Trumper, S., H. Follmann, and I. Haberlein. 1994. A novel dehydroascorbate reductase from spinach chloroplasts homologous to plant trypsin inhibitor. FEBS Lett. 352:159-162.

Vallee, B. and D. Auld. 1990. Zinc coordination, function and structure of zinc enzymes and other proteins. Biochemistry 29:5647-5659.

Vallee, B.L., J.E. Coleman, and D.S. Auld.1991. Zinc fingers, zinc clusters and zinc twists in DNA binding domains. Proc. Natl. Acad. Sci. USA 88:999-1003.

Vasconcellos, L.A.B.C. and W.S. Castle. 1994. Truck xylem anatomy of mature healthy and blighted grapefruit trees of several rootstocks. J. Amer. Soc. Hort. Soc. 119:185-194.

Williams, G.L. and L.G. Albrigo, 1984. Some inorganic element changes in trunk phloem of healthy and blight-affected citrus trees. J. Amer. Soc. Hort. Sci. 109:437-440. 